\title{
MANAGEMENT CONTROL SYSTEMS AND LODGING BUSINESS MODEL IN JAPANESE RYOKANS \\ Tomohiro Kaminaka ${ }^{1}$, Zubir Azhar ${ }^{2}$ \& Dayana Jalaludin ${ }^{3}$ \\ 1,2,3 School of Management, Universiti Sains Malaysia \\ (tomohiro.kaminaka@student.usm.my, zubirazhar@usm.my, dayana@usm.my)
}

\begin{abstract}
The lodging sector in Japan has experienced a shrinking market size of traditional lodging providers (known as ryokans). Ryokans, which account for about $40 \%$ of Japanese lodging market, have operated their lodging businesses based on a unique business model that has been in existence for over 1,000 years. About 30\% of ryokans are in a declining stage, where they are unable to break away from the traditional business models and are in a negative spiral of continuing deficits. The intent of this paper is to understand how ryokans innovate their business model while maintaining some of their traditional fundamental elements. This paper adopts a multiple-case study approach based on the two high-performing ryokans with long histories. Our findings add the ryokans' commercial-cultural context to existing literature that describes the role of management control systems (MCS) in supporting business model innovation. Understanding the achievement of their business model innovation from a long-term perspective of about thirty years provides our paper with theoretical originality. We conclude that the weights of formal and informal controls in MCS are equal in the long term regardless of the direction of their business model innovation. In recent years, tourism policy has encouraged ryokans to use management accounting information to overcome their low-profit businesses. Our practical suggestions complement the tourism policy that presupposes the use of management accounting information alone, and support ryokan managers to use it as a part of MCS. KEYWORDS: Management control systems, Business model innovation, Japanese lodging sector, Ryokans, Qualitative case studies
\end{abstract}

\section{PURPOSE AND BACKGROUND}

The purpose of this paper is to understand the role of management control systems (MCS) in supporting business model innovation of ryokans which have operated as the Japanese lodging business model for over 1,000 years. Although ryokans which account for about $40 \%$ of Japanese lodging market, about $30 \%$ of them could not break away from the traditional business model and are in a negative spiral of continuing deficits.

We are interested in understanding how ryokans under the commercial-cultural context innovate their business model while maintaining some of their traditional elements. MCS which influences human or organizational behavior towards achieving desired organizational goals and strategies acts as an organizational vector in dealing and adapting to change.

\section{METHODOLOGY}

We recognised the literature gap that little is known about MCS practices, including the use of management accounting information, at ryokans operating in a commercial-cultural context. This study conducts a multiple-case study approach based on two high-performing ryokans with long histories of survivability. 
The ryokans were selected due to the following criteria i.e. (a) they have advanced initiatives to help improve innovation and profitability, (b) ryokans which have been operating for over a hundred years in hot-spring areas and family-owned. This appears the typical features of ryokans, therefore this research generalises the theory and analysis. Data was collected via semi-structured interviews with their presidents and head of the corporate planning office.

\section{FINDINGS}

The formal and informal MCS plays an important role in ensuring that the limited management resources are utilized effectively. The MCS exists via the four levers (beliefs, business, boundary, diagnostic and interactive systems), depending on the strategic direction of the respective organizations. The weights of formal and informal controls eventually are equal in the long-term.

\section{CONCLUSION}

While evidence from the case companies clearly supports that there was a strategic direction search between business model innovation and MCS even under commercial-cultural context, it only explained their short-term direction. It can be concluded that even among companies with different strategic directions in the short-term, they will experience equal formal and informal control weights of MCS in the long-term.

\section{CONTRIBUTION/PRACTICAL IMPLICATIONS}

Our conclusions and theoretical originality were drawn by understanding the achievement of business model innovation from a long-term perspective of about thirty years. The study also suggested to ryokan management that it has practical implications for continuous improvement of MCS for business model innovation.

Ryokan management is required to actively utilise management accounting information to improve their efficiency and profitability by Japanese tourism policy. Our findings do not deny management accounting information. However, the best practices of case companies indicate that the control by management accounting does not work without being supported by other formal and informal controls in MCS.

In addition, we proposed to the ryokan management that staff actions could be promoted and regulated through MCS in order to maximise the Japanese hospitality (omotenashi) that represents the ryokans' traditional value.

\section{ACKNOWLEDGEMENTS}

We wish acknowledge the valuable comments from an anonymous reviewer. We also thank the participants from the two ryokans whose cooperate semi-structured interviews.

\section{REFERENCES}

Cosenz, F., \& Bivona, E. (2020). Fostering growth patterns of SMEs through business model innovation. A tailored dynamic business modelling approach. Journal of Business Research, (February). https://doi.org/10.1016/j.jbusres.2020.03.003

Haustein, E., Luther, R., \& Schuster, P. (2014). Management control systems in innovation companies: A literature based framework. Journal of Management Control, 24(4), 343-382. https://doi.org/10.1007/ s00187-014-0187-5 
Simons, R. (1995). Levers of control: How managers use innovative control systems to drive strategic renewal. Boston, MA: Harvard University Press. 